\title{
Internet usage patterns among medical interns of Muzaffarnagar: A comprehensive survey analysis
}

\author{
Sanjeev Davey, Santosh Kumar Raghav, Anuradha Davey², Nirankar Singh¹, J.V. Singh1 \\ Department of Community Medicine, ' ${ }^{1}$ uzaffarnagar Medical College \& Hospital, Muzaffarnagar, ${ }^{2}$ Subharti Medical College, Meerut,
} Uttar Pradesh, India

\section{A B S T R A C T}

Introduction: Internship period of medical interns of India often have a relatively free time after their duty hours, which is nowadays is being more diverted to spending time online on internet, consequently their usage pattern justifies the study in this area. Materials and Methods: A cross-sectional survey was carried out on all medical Interns of one full batch attending department of Community Medicine every month (10 Interns/month-total $=100$ ) of a Private medical College in Muzaffarnagar from $1^{\text {st }}$ July 2013 to $1^{\text {st }}$ July 14 . First approval of ethical committee of the of Institution was sought, followed by Medical interns enlisting and then consent were taken for participation in this study. A pre-tested semi-structured questionnaire was e-mailed to collect data from medical interns while maintaining anonymity and data analysis was done using Epi-info software version 7.1.3.3.Results: Internet usage by Interns was found primarily through Smartphone's (60\%), in which Google search \& Facebook were used in maximum (69\% \& 75\%). The difference between impact of Internet on daily and professional life of interns was found to be highly statistically significant $\left(X^{2}=16.82\right.$, d. $\left.f=1, p<0.001\right)$, but there was no association between monthly amount spent on internet and number of hours spent on Internet $\left(X^{2}=0.74, d f=1, p>0.05\right) .55$ $(55 \%)$ of interns used internet $>100$ hours in a month and that too mainly for PG entrance Preparation and pornographic activities (25\% each). Conclusions: Internet is significantly impacting the daily and professional life of medical Interns as perceived by them and their dominant internet searching habits are harmful to them; so they need proper guidance and counseling services in order to regulate their proper Internet use, which can be further clarified from more in-depth studies in future.

Key words: Internet, Internship, MBBS, Muzaffarnagar, Medical College, Smartphone

\section{INTRODUCTION}

The United nation has recently called for investments in support of generation of youth. ${ }^{1}$ One of the most productive educated youths from Medical Colleges who really shape society's health i.e., MBBS (Medical) Interns are the ones who needs constant skill, training, experiences and guidance not only in their professional life, but also they need expert opinions on their daily life learning skills from their senior PGs, faculties and parents.

Medical interns performance depends on many factors such as good sleep for their better performance in their profession and it has been found that when they are deprived of normal sleep they experience transient psychopathology and decreased efficiency in their performance due to new major factors such as Internet distraction on their life currently [Friedman et al (1971)]. ${ }^{2}$ Literature also reveals that Interns can make more serious medical errors when they work in frequent shifts of 24 hours and their effective performance is possible only, when they are distracted least in their professional and daily life from distractions arising from Internet usage [Landrigan CP (2004)]. ${ }^{3}$

It had been found in Gujarat (India) by Chudasama R et al (2008) if medical students get better access to information technology resources; then they can utilize their knowledge towards computer and internet usage, provided this 
internet technology is used quite judiciously. ${ }^{4}$ Study of Unnikrishnan B et al (2008) in south India had also revealed that; as the MBBS students progress in their years from $1^{\text {st }}$ year to Internship the use of computer for entertainment declines, but use of internet for general information and thesis/research work rises a lot. ${ }^{5}$

Knowledge of good prescribing by the MBBS interns In India is also deficient; as per the study findings of Jaykaran P et al (2008), in which he had found that excessive internet usage by Interns is an important issue. ${ }^{6}$ Study by Krause $\mathrm{R}$ et al (2011) on Internet access in the emergency department of hospital of New York (USA) by residents and interns had also found that; the Internet usage can give a false sense of security in their answers; so it should be studied carefully, before we can reply upon it as a valuable tool for teaching and clinical decision making by the interns and residents. ${ }^{7}$

The study of Lal P et al (2006) on usage of internet among UGs, PGs and SRs in Delhi (India) had revealed that Internet use by them at either at home or at facilities (other than the internet cafe in campus) was 56.6\% among UG students and $78.6 \%$ in the PGs/SRs, $(\mathrm{p}<0.001)$ and overall it was - 62.4\%. ${ }^{8}$ Jadoon NA et al (2011) in Lahore, Pakistan had emphasized from their study that there is under utilization of the potential of internet resources in augment learning areas due to reasons such as: a) Increase in awareness, b) availability of requisite facilities and c) training in computing skills which are required in order to have better utilization of digital resources by medical students. ' Study by Kumar S (2013) in Birgang, Nepal on 250 medical students had also observed an association between the year of study and the purpose of computer and internet use, which is getting more frequent nowadays among medical students across the world. ${ }^{10}$

Keeping in view of the emerging internet usage studies in literature among medical UG students, PG students and Junior/Senior residents and with availability of practically no studies that focus specifically on medical MBBS interns internet usage patterns in private medical colleges of India where students often come from good socioeconomic background and have enough time during their internship period for spending on internet; therefore this study focus specifically on this emerging issue of internet usage patterns among them, leading to selection of this research topic by authors in this article.

\section{MATERIALS AND METHODS}

\section{Research question}

What are the modes and usage patterns of Internet among Medical Interns of a Private Medical College in India(Muzaffarnagar-UP)?

\section{Ethical approval}

First approval of ethical committee of the of Institution was sought, followed by Medical interns enlisting and finally consent for their participation in the study were taken.

Place of study

Private Medical college in Muzaffarnagar (Uttar PradeshIndia).

\section{Study duration}

From $1^{\text {st }}$ July 2013 to $1^{\text {st }}$ July 2014.

\section{Study design}

A Cross-sectional survey.

\section{Study participants}

All MBBS medical Interns of one full batch attending department of Community Medicine every month (10 Interns $/$ month-total $=100$ medical interns) of a Private medical College in India -Muzaffarnagar district of state Uttar Pradesh.

\section{Data collection strategy}

For collecting data a pre-tested semi-structured questionnaire was e-mailed to collect data from medical interns after giving a specific number to each intern as per list received from principal office and their names were not sought in Performa.

Data analysis methods

It was done using Epi-info software version 7.1.3.3.

\section{Statistical tests used}

The statistical significance of study findings was tested by applying Chi-Square test.

\section{RESULTS}

The majority of interns were in age group of 20-25 years (75\%), with family income between 10-20 lakhs and monthly pocket money between 5000-10,000 (50\% each) with equal sex distribution (50\% each) (Table 1$)$.

The mode of assessment of Internet by Interns was primarily through Smartphone's (60\%), in which Google search \& Facebook were used in maximum $(69 \%$ \& $75 \%)$ and $55 \%$ were using Internet from $<$ than 5 years. $62 \%$ of our interns spent $>$ than 100 rupees and $55 \%$ used Internet for $>$ than 100 hours in a month in which search for PG Medical entrance Preparation, sex websites search (25\% each) and downloading apps from Google Play store (10\%) were their dominant search habits (Table 2).

$65 \%$ vs $35 \%$ of Interns felt that Internet impact on daily vs professional life was harmful. Nearly $30 \%$ of medical 


\begin{tabular}{|c|c|c|c|}
\hline S.No & $\begin{array}{l}\text { Socio-economic } \\
\text { parameters considered }\end{array}$ & $\begin{array}{l}\text { No of interns } \\
(N=100)\end{array}$ & $\%$ \\
\hline 1. & $\begin{array}{l}\text { Age group (in years) } \\
<\text { than } 25 \text { years } \\
>\text { than } 25 \text { years }\end{array}$ & $\begin{array}{l}75 \\
25\end{array}$ & $\begin{array}{l}75 \\
25\end{array}$ \\
\hline 2. & $\begin{array}{l}\text { Sex } \\
\text { Male } \\
\text { Female }\end{array}$ & $\begin{array}{l}50 \\
50\end{array}$ & $\begin{array}{l}50 \\
50\end{array}$ \\
\hline 3. & $\begin{array}{l}\text { Annual family Income (in Rs/) } \\
\text { <10 Lakhs } \\
\text { 10-20 Lakhs } \\
>20 \text { Lakhs }\end{array}$ & $\begin{array}{l}25 \\
50 \\
25\end{array}$ & $\begin{array}{l}25 \\
50 \\
25\end{array}$ \\
\hline 4. & $\begin{array}{l}\text { Monthly Amount of Pocket } \\
\text { Money received (in Rs/) } \\
\quad<5000 \\
5000-10,000 \\
>10,000\end{array}$ & $\begin{array}{c}45 \\
50 \\
5\end{array}$ & $\begin{array}{c}45 \\
50 \\
5\end{array}$ \\
\hline
\end{tabular}

interns felt that they not only remained online majority of the times, but they also (same 30\%) felt that Internet usage helped themselves in PG medical entrance preparation (Table 3 and Figures 1 and 2).

Although difference between impact of Internet on daily and professional life of interns was highly statistically significant $\left(\mathrm{X}^{2}=16.82\right.$, d.f $\left.=1, \mathrm{p}<0.001\right)$ but we found, there was no association between monthly amount spent on internet and no. of hours spent on Internet (Chi-square test: $\left.\mathrm{X}^{2}=0.74, \mathrm{df}=1, \mathrm{p}>0.05\right)$ (Table 4 and 5).

\section{DISCUSSION}

In India, Private Medical Colleges are educational institutions that provide medical education on donation basis. These institutions also train doctors in all aspects of medical care, apart from government medical colleges. Muzaffarnagar Medical College (MMC) is a private medical educational institution in western Uttar Pradesh, India, which provides low cost health care to the surrounding rural areas of Muzaffarnagar district, Meerut district, Saharanpur district etc as well as medical education (UG \& PG courses) for students.

Compulsory Rotatory Residential Internship (CRRI) is a one-year compulsory work in the hospital attached to the medical college by students who have passed final year MBBS examination. ${ }^{11}$ A Medical Intern/Internee or a CRRI is posted in all the clinical departments of the hospital on a rotation basis, in order to give the basic clinical experience in all the disciplines of medicine and which enables him/her to work as a General Physician. The Permanent registration certificate along with the MCI Registration number and the final Medical degree is given only after obtaining a CRRI completion

\begin{tabular}{|c|c|c|c|}
\hline S.No & $\begin{array}{l}\text { Internet usage parameters } \\
\text { considered }\end{array}$ & $\begin{array}{l}\text { No of interns } \\
(N=100)\end{array}$ & $\%$ \\
\hline \multirow[t]{5}{*}{1.} & Mode of assessing the Internet & & \\
\hline & Desktop & 05 & 05 \\
\hline & Laptop & 13 & 13 \\
\hline & Smartphone's & 60 & 60 \\
\hline & Tablet & 22 & 22 \\
\hline \multirow[t]{6}{*}{2.} & Internet search engines accessed most & & \\
\hline & Google & 69 & 69 \\
\hline & Yahoo & 11 & 11 \\
\hline & MSN & 05 & 05 \\
\hline & Rediff & 06 & 06 \\
\hline & You Tube & 09 & 09 \\
\hline \multirow[t]{6}{*}{3.} & $\begin{array}{l}\text { Types of Social Net-working websites } \\
\text { accessed most }\end{array}$ & & \\
\hline & Facebook & 75 & 75 \\
\hline & Twitter & 03 & 03 \\
\hline & Orkut & 01 & 01 \\
\hline & Whats Up & 12 & 12 \\
\hline & We Chat & 09 & 09 \\
\hline \multirow[t]{3}{*}{4.} & $\begin{array}{l}\text { Amount of monthly expenditure on } \\
\text { internet }(n=100)\end{array}$ & & \\
\hline & $<100$ (in Rs) & 38 & 38 \\
\hline & $>100$ (in Rs) & 62 & 62 \\
\hline \multirow[t]{11}{*}{5.} & $\begin{array}{l}\text { No of hours spent on Internet in a } \\
\text { month }(n=100)\end{array}$ & & \\
\hline & $<100$ (hrs) & $\mathrm{N}=45$ & $\%$ \\
\hline & Use it mainly for chatting & 5 & 5 \\
\hline & Search for PG entrance preparation & 25 & 25 \\
\hline & $\begin{array}{l}\text { Search for new researches in } \\
\text { medical sciencies }\end{array}$ & 2 & 2 \\
\hline & Search for medical books & 3 & 3 \\
\hline & Search for personal work & 10 & 10 \\
\hline & $>100$ (hrs) & $\mathrm{N}=55$ & $\%$ \\
\hline & For Pornographic web search & 25 & 25 \\
\hline & Do online shopping mostly & 10 & 10 \\
\hline & $\begin{array}{l}\text { For downloading apps from Google } \\
\text { play store }\end{array}$ & 20 & 20 \\
\hline \multirow[t]{4}{*}{6.} & No of years from which using Internet & & \\
\hline & $<5$ & 55 & 55 \\
\hline & $5-10$ & 40 & 40 \\
\hline & $>10$ & 5 & 5 \\
\hline
\end{tabular}

certificate endorsing the successful and satisfactory completion of the CRRI.

The schedules of a Medical intern is often very exhaustive e.g 24-hour sleepless duty at a stretch is not uncommon. He or she is although paid a monthly stipend for his work in the hospital which differs in different private medical colleges on the basis of their management. The medical intern is then licensed to practice medicine only after completion of this internship and can receive his MBBS degree and can pursue postgraduate studies later on. All this is possible effectively only when they get least distractions from new kind of distracter in Interns life i.e Proliferative growth of Smartphone's internet usage.

Medical Professionals including students, interns and residents currently use the computer and internet not only 


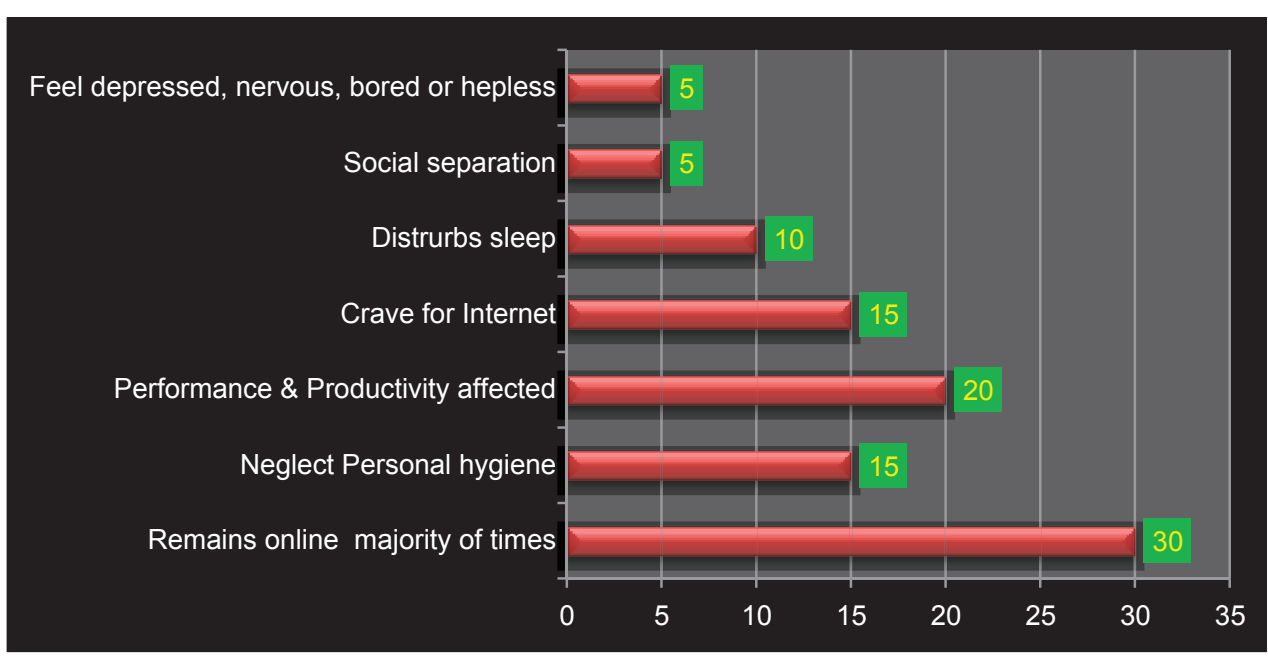

Figure 1: Perception of harmful impacts of internet on daily and professional life of medical interns

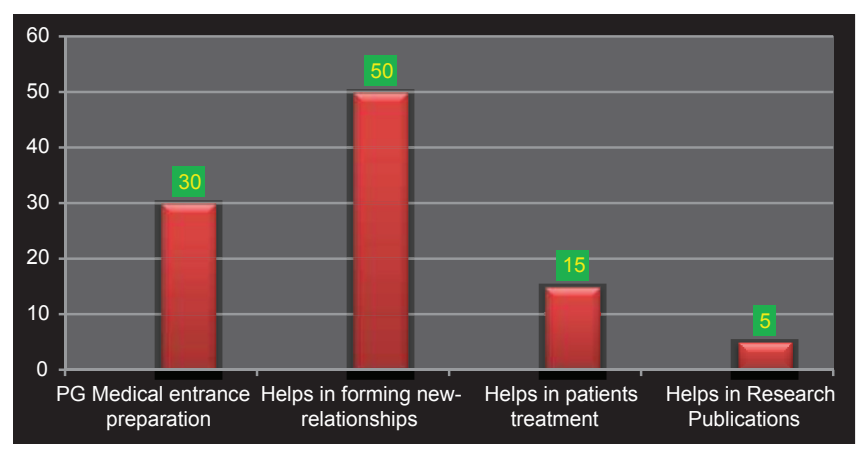

Figure 2: Perception of useful impacts of Internet on daily and professional life of medical interns

\begin{tabular}{|c|c|c|c|}
\hline S.No & Responses & $\begin{array}{l}\text { No of interns } \\
(\mathrm{N}=100)\end{array}$ & $\%$ \\
\hline \multirow[t]{3}{*}{1.} & Internet impact on daily life & & \\
\hline & Harmful & 65 & 65 \\
\hline & Useful & 35 & 35 \\
\hline \multirow[t]{3}{*}{2.} & Internet impact on professional life & & \\
\hline & Harmful & 35 & 35 \\
\hline & Useful & 65 & 65 \\
\hline \multirow[t]{8}{*}{3.} & $\begin{array}{l}\text { Internet impact on daily \& } \\
\text { professional life -harmful }(n=100)\end{array}$ & & \\
\hline & Remains online majority of times & 30 & 30 \\
\hline & Neglect personal hygiene & 15 & 15 \\
\hline & Performance \& productivity affected & 20 & 20 \\
\hline & Crave for internet & 15 & 15 \\
\hline & Distrurbs sleep & 10 & 10 \\
\hline & Social separation & 5 & 5 \\
\hline & $\begin{array}{l}\text { Feel depressed, nervous, bored or } \\
\text { hepless }\end{array}$ & 5 & 5 \\
\hline \multirow[t]{5}{*}{4.} & $\begin{array}{l}\text { Internet impact on daily \& } \\
\text { professional life -useful }(n=100)\end{array}$ & & \\
\hline & PG Medical entrance preparation & 30 & 30 \\
\hline & Helps in forming new-relationships & 50 & 50 \\
\hline & Helps in patients treatment & 15 & 15 \\
\hline & Helps in Research Publications & 5 & 5 \\
\hline
\end{tabular}

\begin{tabular}{|c|c|c|c|}
\hline S.No. & $\begin{array}{l}\text { Study parameters } \\
\text { chosen }\end{array}$ & $\begin{array}{l}\text { Harmful } \\
(n=100)\end{array}$ & $\begin{array}{l}\text { Useful } \\
(n=100)\end{array}$ \\
\hline 1. & Professional life of Interns & 35 & 65 \\
\hline 2. & Daily life of Interns & 65 & 35 \\
\hline
\end{tabular}

\begin{tabular}{|c|c|c|}
\hline $\begin{array}{l}\text { Study parameters } \\
\text { chosen }\end{array}$ & $\begin{array}{l}\text { No of interns who } \\
\text { spent monthly } \\
\text { money on } \\
\text { Internet }(n=100)\end{array}$ & $\begin{array}{c}\text { No of interns } \\
\text { who spent } \\
\text { hours on } \\
\text { Internet }(n=100)\end{array}$ \\
\hline$<100$ (Rs/Hours) spent & 38 & 45 \\
\hline$>100$ (Rs/Hours) spent & 62 & 55 \\
\hline
\end{tabular}

for both social communication \& educational purposes but also they use internet to stay online and enhance their social lives. ${ }^{10,12}$ The time has come that computer assisted teaching learning activities needs encouragement for the improvement of medical science for the new generations as found in study by Kumar S (2013) and this is similar to our study findings and recommendations. ${ }^{10}$

The use of computerized information systems by medical professionals can get better the quality of care, enhance the use of evidence based treatment, and maintain and update knowledge. The medical students and interns also need training to learning on how to use web-based search tools and techniques to obtain high-quality information resources and they also need self-directed learning in order to acquire life-long learning skills from internet. ${ }^{10,13,14}$ 
Study of Lal P et al (2006) had found that among the purposes of accessing the internet at the internet cafe in campus and at home/other facilities-included educational uses, receiving or sending an e-mail, surfing, chatting and entertainment etc and this use of the internet for educational purpose was higher among the PGs/SRs while use for surfing, chatting and entertainment was observed to be higher among the UG students and these findings are similar to our study and other studies in literature. ${ }^{8,15}$

The majority of interns were in our study had family income between 10-20 lakhs and monthly pocket money provided to them was between Rs. 5000-10,000. The majority of students entering private medical colleges of India are often from very rich family and they have got very easy access to many kind of internet devices such as Smartphone's, which are expanding at a rapid rate in developing countries such as India.

We also found that the mode of assessment of Internet by Interns was primarily through Smartphone's (60\%), these findings in our study is similar to study of Connor PO et al (2014) in which they also found that Smartphones were used by the majority of interns on a daily basis in order to perform their job; but they had suggested that interns need advice on the usage of credible medical apps and websites in their professional life, which is also the recommendation of our study. ${ }^{16}$

We found in our study that the Google search engine was searched significantly $(69 \%)$ and $55 \%$ were using Internet from < than 5 years as similar to the study by Banerjee I et al (2011) in which they also found that common search engines browsed by both UGs and PGs were Google and yahoo. $^{17}$

In our study we also found that, $65 \%$ vs $35 \%$ of Interns felt that Internet impact on daily vs professional life were not useful and these findings were similar to study by Maroof KA et al (2012) in which they had found that their nearly $8.0 \%$ of the students felt that Internet is totally useless in medical field. ${ }^{18}$ In our study nearly $30 \%$ of medical interns felt that they not only remained online majority of the times, but they also (same $30 \%$ ) felt that Internet usage helped themselves in PG medical entrance preparation and nearly $62 \%$ interns spent $>100$ rupees and $55 \%$ used Internet for $>100$ hours in a month, although this finding is in contradiction findings of the study by Maroof KA et al (2012) in which they had found that majority of the medical students accessed Internet at least for less than 3 hours per week, which suggests that there is a wide subjectivity and variation in internet usage by MBBS students. ${ }^{18}$
In our study we found that although difference between impact of Internet on daily and professional life of interns was highly statistically significant $\left(X^{2}=16.82\right.$, d.f $=1, p<0.001)$ but we found, there was no association between monthly amount spent on internet and no. of hours spent on Internet (Chi-square test: $\mathrm{X}^{2}=0.74, \mathrm{df}=1$, $\mathrm{p}>0.05)$ and this is similar to addictive internet use study among medical students, PGs, JRs and SRs by Chathoth V et al (2014). ${ }^{19}$

In our study we found that facebook were used in maximum $(75 \%)$ and facebook addictive use came out to be a very important concern among medical interns; very similar to the study by Dubai SA RA et al (2013) in which they had also found that the average hours spent on facebook were associated with adverse health effects and unhealthy behaviors among medical students, as well as social isolation from the family and community. ${ }^{20}$

\section{Limitations of study}

We did only a small survey of 100 Medical interns from a single batch of a one private medical college excluding $1^{\text {st }}$ to $4^{\text {th }}$ year MBBS students, PGs, JRs and SRs, so issue of generalization of study findings can be a debatable one.

\section{CONCLUSIONS}

Internet nowadays is significantly impacting the daily and professional life of medical Interns as found in our study and their patterns of internet usage are also harmful; so they need proper guidance and counseling services from department of Community medicine and Psychiatry in order to regulate their Internet use, otherwise in future they can have negative consequences in all spheres of their life. We therefore suggest some regulatory strategies from either Government of India or MCI or Private Medical Colleges itself regarding monitoring and supervision of Smartphone's internet access by Medical interns. So this can be further studied in larger samples of medical interns at many medical colleges of India via in-depth qualitative and quantitative approach in future, so as to get a more clarified picture on this area.

\section{LIST OF ABBREVIATIONS USED}

- UG-Under Graduate Student

- PG- Post Graduate Student

- JR-Junior Resident

- SR-Senior Resident

- MCI-Medical Council of India

- MBBS- Medicine Bachelor \& Bachelor of Surgery

- $\mathrm{X}^{2}$-Chi Square 


\section{ACKNOWLEDGMENTS}

We are extremely thankful to the Dr Tauseef Alvi (medical Intern) for his help in data collection, as well as the whole Office staff of department of Community Medicine and last but not the least the HOD Community Medicine, Principal, Director and Chief hospital administrator for their approval of this study at institution.

\section{REFERENCES}

1. World Population Day Theme: Investing in Young People. http://www.un.org/en/events/populationday/. 2014. Retrieved 31/07/2014, 12,50 hours.

2. Friedman RC, Bigger J, Kornfeld T and Donald S. The intern and sleep loss. The New England Journal of Medicine 1971; 285(4): 201-203.

3. Landrigan CP, Rothschild JM, Cronin JW, Kaushal R, Burdick E, Katz JT, et al. Effect of Reducing Interns' Work Hours on Serious Medical Errors in Intensive Care Units. New England Journal of Medicine 2004;351:1838-1848.

4. Chudasama R,Godara N and Srivastava R. Assessing computer literacy and attitude towards e-learning among final year medical students. The Internet Journal of Medical Informatics 2008;5 (1):11322.

5. Unnikrishnan B, Kulshrestha V, Saraf A, Agrahari AC, Prakash S, Samantaray L, et al. Pattern of computer and internet use among medical students in Coastal South India. South East Asian Journal of Medical Education 2008; 2(2):1-8.

6. Jaykaran P, Bhardwaj N, Chavda P and Yadav AP. Prescribing knowledge of the intern doctors in India. Internet Journ of Epidemiology 2008;7(1):13681.

7. Krause R, Moscati R, Halpern S, Schwartz DG and Abbas J. Can Emergency Medicine Residents Reliably Use the Internet to Answer Clinical Questions? Western Journal of Emergency Medicine 2011;12(4):442-447.

8. Lal P, Malhotra R, Ahuja C and Ingle GK. Internet use Among Medical Students and Residents of A Medical College of North India. Indian Journal of Community Medicine 2006; 31(4): 293-294.
9. Jadoon NA, Zahid MF, Mansoorulhaq H, Ullah S, Jadoon BL, Raza A, et al. Evaluation of internet access andutilization by medical students in Lahore, Pakistan. Bio Med Central Medical Informatics and Decision Making 2011; 11:37.

10. Kumar S. Use of Computer among Medical students: A cross sectional study. Journal of Medical Science 2013; 1(1): 15-18.

11. Rules and regulations for medical graduates from the Medical Council of India. GAZETTE OF INDIA DATED.1997. http://www.mciindia.org/RulesandRegulations/ GraduateMedicalEducationRegulations1997.aspx.Retrieved $31 / 7 / 2014,1.45$ hours

12. Jones, S. The Internet Goes to College, Internet \& American life. 2002 Sep 15 http://www.pewinternet.org. Retrieved 31/7/2014 2.00hours

13. Romanov $\mathrm{K}$ and Aarnio MA. Survey of the use of electronic scientific information resources among medical and dental students. Bio Med Central Medical Education 2006: 9(6):28.

14. Mony PK, George KC and Chacko N. Computer use among postgraduates of a medical college in southern India. National Medical Journal of India 2004;17(3):175-176.

15. Inamdar SC and Rotti SB. Computer use among medical students in an institution in southern India. National Medical Journal of India 2004; 17: 8-10.

16. Connor PO, Byrne D, Butt M, Offiah G, Lydon S, Mc Inerney K, et al. Interns and Their Smartphones: Use for Clinical Practice. Postgraduate Medical Journal 2014;90(1060):75-79.

17. Banerjee I, Biswas S, Biswas A, De M, Begum SA and Haldar S. Trends to access internet among medical students of a government medical college in West Bengal. Journal of Indian Med Association 2011;109(7):459-461.

18. Maroof KA, Parashar $P$ and Bansal R. How are our medical students using the computer and internet? A study from a medical college of north India. Nigerian Medical Journal 2012; 53(2): 89-93.

19. Chathoth V, Kodavanji B, Kumar NA, Anupama N, Kini D R and Pai SR. Impact of internet use on lifestyle in undergraduate medical students. International Journal of Biomedical Research 2014; 05 (03):0-3.

20. Dubai SR, Ganasegeran K, Shagga MA, Yadav H and Arokiasamy JT. Adverse Health Effects and Unhealthy Behaviors among Medical Students Using Facebook. The Scientific World Journal 2013; http://dx.doi.org/10.1155/2013/465161.Retrieved $31 / 07 / 2014,1500$ hours.

Authors Contribution:

$1 \& 2$ authors have contributed equally to article, 3 Guided and edited the article.

OUA - Conceived and designed the study, made the first draft of the manuscript; PAI - Concept and design of the study, analysis and interpretation of data; AEO - Literature searches and manuscript preparation.

Source of Support: Nil, Conflict of Interest: None declared. 